\title{
The heat stress for workers employed in a dairy farm
}

\author{
Alvaro Marucci, Danilo Monarca, Massimo Cecchini, Andrea Colantoni, \\ Simone Di Giacinto, Andrea Cappuccini \\ Department of Agriculture, Forests, Nature and Energy, University of Tuscia, Viterbo, Italy
}

\begin{abstract}
The Italian dairy production is characterized by high heterogeneity. The typology quantitatively more important ( $80 \%$ of national production) is represented by cow's milk cheeses (Grana Padano cheese, string cheese, Parmesan cheese, etc.), while the cheese from buffalo's milk (especially string cheese such as mozzarella) and cheese from sheep and goats represents respectively $4 \%$ and $8 \%$ of the national dairy production, and are linked to specific regional contexts. Some phases of the cycle of milk processing occur at certain temperatures that are not comfortable for the workers also in relation to possible problems due to thermal shock. The aim of this study was to evaluate the risk of heat stress on workers operating in a dairy for processing of buffalo milk. The research was conducted at a dairy farm located in the province of Viterbo, Italy, during the spring-summer period. To carry out the research were detected major climatic parameters (air temperature, relative humidity, mean radiant temperature, air velocity) and the main parameters of the individual operators (clothing thermal insulation and the energy expenditure required from the work done by employees). Subsequently, main indices of heat stress assessment provided by the main technical standards were calculated. In particular have been calculated predicted mean vote and predicted percentage of dissatisfied in moderate thermal environments (environments in which the objective, in the design and management phases, is to achieve the thermal comfort), provided by the UNI EN ISO 7730 and the wet bulb globe temperature in severe hot environments (environments in which you must protect the health of workers) required by UNI EN ISO 27243. The results show some phases of risk from heat stress especially during times of test in which the internal air temper-
\end{abstract}

Correspondence: Alvaro Marucci, Department of Agriculture, Forests, Nature and Energy (D.A.F.N.E.), University of Tuscia, via S. Camillo de Lellis snc 01100 Viterbo, Italy.

Tel. +39.0761 .357365 - Fax: +39.0761 .357453 .

E-mail: marucci@unitus.it

Key words: dairy farm, heat stress, microclimate.

Received for publication: 9 0ctober 2013.

Accepted for publication: 7 January 2014.

(C) Copyright A. Marucci et al., 2013

Licensee PAGEPress, Italy

Journal of Agricultural Engineering 2013; XLIV:218

doi:10.4081/jae.2013.218

This article is distributed under the terms of the Creative Commons Attribution Noncommercial License (by-nc 3.0) which permits any noncommercial use, distribution, and reproduction in any medium, provided the original author(s) and source are credited. ature exceeds the threshold of $30^{\circ} \mathrm{C}$ and possible solutions to improve the safety of the operators.

\section{Introduction}

During the summer Mediterranean areas are charaterized by high values of solar radiation, coming to $1000 \mathrm{~W} \mathrm{~m}^{-2}$, and consequently high values of air temperature that can reach $40^{\circ} \mathrm{C}$ (Marucci et al., 2013).

The issues related to the microclimate in the workplace are connected to the environmental factors that affect the thermal exchanges between man and the environment. In many agricultural and agroindustrial workplaces, the thermal comfort is difficult to achieve. In fact, the man is often found to operate outdoors or in the presence of animals, or in high temperature conditions (greenhouses) or very low (cold storage) or in situations where climatic parameters must be kept within specific microclimatic intervals, to ensure products conform to the standards of preparation, ripening and storage of products.

The main factors that influence these exchanges are: the weather conditions outside, the structural characteristics of the building, the characteristics of air conditioning (cold, hot), the number of occupants in environment to be examined and the type of activity. Of particular importance is also, especially in the agro-food industries, the presence of thermal excursions such as to endanger the health of workers (Monarca et al., 2012).

In dairy farms remain, even where the level automation is high, many risk conditions for health of workers (Di Giacinto et al., 2012). Among these, it is includes the feeling of thermal discomfort perceived by employees, due to the microclimatic conditions (Marras et al., 2005).

The milk processing within a dairy varies according to the type of product to be obtained with a consequent variation of the optimal microclimatic conditions, which are often in contrast with those relating to the feeling of thermal comfort of workers. In particular, in the case of the buffalo's mozzarella processing (Figure 1), the phase greatest risk with regard to heat stress is that relating to the spinning.

Therefore, it is necessary to analyze such working conditions and the impact on the worker's health and be taken appropriate measures to improve the staff working conditions (Marucci et al., 2012).

The risk assessment of thermal stress is evaluated using microclimatic indices (Alfano et al., 1998; Moran et al., 2001; Pérez-Alonso et al., 2011; Callejon-Ferre et al., 2011) based on the safety legislations that take into account climatic factors, the activities carried out by operators and clothing used (Budd, 2008). The goal of this research is to assess the risk of heat stress for workers that operate within a dairy farm used as processing of buffalo's milk.

The research was conducted in a dairy farm located in the municipality of Alto Lazio during the spring-summer period and were subsequently determined the assessment heat stress indices provided by the main technical standards: UNI EN ISO 7730 (ISO, 2006) for the determination of the predicted mean vote index (PMV) and predicted per- 
centage of dissatisfied index (PPD) in moderate environments and UNI EN ISO 27243 (ISO, 1996) for the calculation of the wet bulb globe temperature index (WBGT) in hot severe environments.

\section{Materials and methods}

The technical standards used for the risk assessment of thermal stress are those represented by the International Organization for Standardization (ISO) standard, implemented in Italy as UNI. In particular, the following standards were applied:

- EN ISO 7730:2006 - Ergonomics of the thermal environment. Analytical determination and interpretation of thermal comfort using calculation of the PMV and PPD indices and local thermal comfort criteria (ISO, 2006);

- EN ISO 27243:1996 - Hot environments. Estimation of the heat stress on working man, based on the WBGT-index (wet bulb globe temperature) (ISO, 1996);

- EN IS0 8996:2005 - Ergonomics of the thermal environment. Determination of metabolic rate (ISO, 2005);

- EN IS0 9920:2009 - Ergonomics of the thermal environment. Estimation of thermal insulation and water vapour resistance of a clothing ensemble (ISO, 2009);

- EN ISO 7726:2002 - Ergonomics of the thermal environment. Instruments for measuring physical quantities (ISO, 2002).

In order to determine the indices proposed by the reference standards were detected microclimatic parameters (temperature and relative humidity inside and outside) of a dairy farm (Figure 2) located in a municipality of Alto Lazio (altitude: $464 \mathrm{~m}$; latitude: $42^{\circ} 32$ ' 17 ' N; longitude: $12^{\circ} 03^{\prime} 19^{\prime \prime} \mathrm{E}$ ) during the spring-summer period. The measurements were performed during the production process of mozzarella (34 p.m.) in the phases of: milk curdling, cutting and bleeding of curd, spinning and forming of mozzarella, and three employees working within the dairy during this phases.

The measurement system used is the following (Figure 3): i) multiacquiring LSI BABUC M instrument with 6 inputs; ii) probes for measuring micro-climatic parameters (thermometer, psychrometer, anemometer and globe thermometer); iii) prop for probes; iv) tripod.

The probes were put into position on a tripod at a height of $1.50 \mathrm{~m}$ from the ground. The PMV index is the average rating from a large sample of people present in the same environment and is a mathemat- ical function (1) that depends on several factors:

$$
\begin{aligned}
& P M V=[0.303 \cdot \exp (-0.036 \cdot M)+0.028] \cdot \\
& \left\{\begin{array}{l}
(M-W)-3.05 \cdot 10^{-3} \cdot\left[5733-6.99 \cdot(M-W)-p_{a}\right]-0.42 \cdot[(M-W)-58.15] \\
-1.7 \cdot 10^{-5} \cdot M \cdot\left(5867-p_{a}\right)-0.0014 \cdot M \cdot\left(34-t_{d}\right) \\
-3.96 \cdot 10^{-8} f_{d} \cdot\left[\left(t_{d}+273\right)^{4}-\left(t_{c}+273\right)^{4}\right]-f_{d} \cdot h_{c} \cdot\left(t_{d}-t_{a}\right)
\end{array}\right\}
\end{aligned}
$$

where:

$\mathrm{M}=$ metabolic rate $\left(\mathrm{Wm}^{-2}\right)$;

$\mathrm{W}=$ effective mechanical power $\left(\mathrm{Wm}^{-2}\right)$;

$\mathrm{f}_{\mathrm{cl}}=$ clothing surface area factor;

$\mathrm{t}_{\mathrm{a}}=$ air temperature $\left({ }^{\circ} \mathrm{C}\right)$ (parameter acquired);

$\mathrm{t}_{\mathrm{r}}=$ mean radiant temperature $\left({ }^{\circ} \mathrm{C}\right)$ (parameter acquired);

$\mathrm{p}_{\mathrm{a}}=$ water vapour partial pressure $(\mathrm{Pa})$;

$\mathrm{h}_{\mathrm{c}}=$ convective heat transfer coefficient $\left(\mathrm{W} \mathrm{m}^{-2} \mathrm{~K}^{-1}\right)$;

$\mathrm{t}_{\mathrm{cl}}=$ clothing surface temperature $\left({ }^{\circ} \mathrm{C}\right)$.

Climatic parameters have been calculated using climate data collected on the farm during the days April $10^{\text {th }}$, May $3^{\text {rd }}$, May $30^{\text {th }}$, June $11^{\text {th }}$ and June $17^{\text {th }}, 2013$, while the metabolism rate (M) and clothing insulation $\left(\mathrm{I}_{\mathrm{cl}}\right)$ of workers have been determined on the basis of existing legislation and the conditions of workload and of clothing detected in trial days. It was taken on value of metabolic rate (M) equal to $116 \mathrm{~W}$ $\mathrm{m}^{-2}(2.0 \mathrm{met})$, as reported in legislation that corresponds to a medium activity and standing. The clothing used by workers is underpants, boiler suit, socks, shoes that corresponds to an $\mathrm{I}_{\mathrm{cl}}$ equal to 0.75 clo $\left(0.11 \mathrm{~m}^{2}\right.$ $\left.\mathrm{K} \mathrm{W}^{-1}\right)$.

ISO 7730 defines the scale of values of the PMV (Table 1) in range +3 (very hot) to -3 (very cold) (ISO, 2006). There are intermediate situations where the 0 corresponds to thermal neutrality; the range between -0.5 and +0.5 corresponds to the thermal comfort. When -2 $<$ PMV $<-0.5$ and $+0.5<$ PMV $<+2$ the thermal environment is moderate while the PMV values less than -2 and greater than +2 the thermal environment is severe.

The same standard defines PPD as the percentage of thermally dissatisfied people and is calculated according to the following function (2):

$$
P P D=100-95 \cdot e^{-\left(0.03353 P M V^{4}-0.2179 P M V^{2}\right)}
$$

The PPD is equal to $10 \%$ in the case where the PMV is within the

Table 1. Thermal sensation scale.

$\begin{array}{lll}\text { PMV } & \text { Seven-point thermal sensation scale } & \text { Classification working environment } \\ +3 & \text { Hot } & \text { Severe hot environment } \\ +2.5 & & \text { Moderate warm environment } \\ +2 & \text { Warm } & \\ +1.5 & \text { Slightly warm } & \\ +1 & & \text { Thermal comfort } \\ +0.5 & \text { Neutral (thermal neutrality) } & \\ 0 & \text { Slightly cool } & \text { Moderate cool environment } \\ -0.5 & \text { Cool } & \\ -1 & \text { Cold } & \text { Severe cold environment } \\ -1.5 & & \end{array}$


range of thermal comfort $(-0.5<\mathrm{PMV}<+0.5)$, while for severe environments the PPD assumes values higher than $80 \%$.

PMV has allowed to classify the thermal environment considered as hot. Consequently, it was necessary to calculate another index proposed legislation for harsh hot thermal environments: WBGT.

Wet bulbe globe temperature is used to determine the thermal stress for individuals acclimated. The current legislation proposes two equations for calculating the WBGT as a function of the presence or absence of sunshine. In this farm, the indoor lighting is completely artificial and therefore without the entry of sunlight. Therefore, the equation that has been applied is that relating to environments not sunny (3):

$$
W B G T=0.7 t_{n w}+0.3 t_{g}
$$

for internal and external exposition without exposure to sun, where: - $\mathrm{t}_{\mathrm{nw}}$ is Natural wet-bulb temperature $\left({ }^{\circ} \mathrm{C}\right)$;

- $\mathrm{t}_{\mathrm{g}}$ is globe thermometer temperature $\left({ }^{\circ} \mathrm{C}\right)$.

\section{Results and discussion}

The measured values of temperature and relative humidity of the air and the calculated values of PMV and PPD during the processing of milk, in the test period, have given the mean values reported in Table 2. From the measurements performed in this period, the indoor air temperature is always higher than $20^{\circ} \mathrm{C}$. In the last two measurement periods, which fall in June, the indoor air temperature was higher than $25^{\circ} \mathrm{C}$. The high values of the internal air temperature in the dairy farm are due to the processing of milk and they can cause serious health problems of the operators especially in the event of prolonged exposure. The relative humidity measured inside the dairy farm is between $50 \%$ and $80 \%$, has not been reached the saturation of the air and this has allowed to reduce the risks associated with the high air temperature.

Figure 4 shows the mean values of the PMV and PPD, calculated with the climate data collected from 3 p.m. to 4 p.m. for each day of measurement inside the dairy, and the limit $(+2)$ beyond which the environment changes from moderate to severe hot. On the first day of the experimental period (April, $10^{\text {th }}$ ), taking into account the thermal energy produced during metabolic activity by workers and thermal insulation of the clothing, the PMV is equal to +1.32 placing itself in the middle between slightly warm and warm in the seven-point thermal sensation scale reported by the legislation. The PPD associated with this PMV value was equal to $41.2 \%$. In the other days of measurements instead PMV index always exceeds the limit of +2 due to the high indoor values of air temperature and relative humidity measured, and other conditions being equal. Exceeding this limit allows to classify the processing environment as severe hot

On June $17^{\text {th }}$, the PMV was not calculated because the air temperature has exceeded the value of $30^{\circ} \mathrm{C}$. Where the PMV index exceeds the threshold of +2 , and thus the work environment becomes severe hot, and the indoor air temperature exceeds $30^{\circ} \mathrm{C}$ is necessary to calculate another index proposed by microclimate safety regulations: the WBGT, through which it is possible to verify if operators are subjected to heat stress.

Figure 5 shows the mean values of WBGT index for the periods of experimentation and the limit for acclimated subjects $\left(26.7^{\circ} \mathrm{C}\right)$.

In the first day of observation (April, $10^{\text {th }}$ ) has not been calculated the WBGT index because the working environment was found to be moderate $(+0.5<$ PMV $<+2)$. Only in the last day (June, $\left.17^{\text {th }}\right)$, WBGT values are higher than the limit established by law for acclimated subjects $\left(26.7^{\circ} \mathrm{C}\right)$. During these reliefs the WBGT was found to be equal to $32.7^{\circ} \mathrm{C}$ showing how the workers were subjected to a real thermal stress. In general, the search results allow to affirm that, under the climatic conditions in which the dairy farm is located, during the second part of the spring season (late April-mid June) the workers are in the presence of a situation of thermal discomfort but they are not subjected to thermal stress since the WBGT was found to be always lower than the limit established by law. In order to reduce the $\mathrm{I}_{\mathrm{cl}}$ index, and so the thermal discomfort, it is possible modify operator's clothing. A significant improvement of the conditions would be obtained to passing a clothing

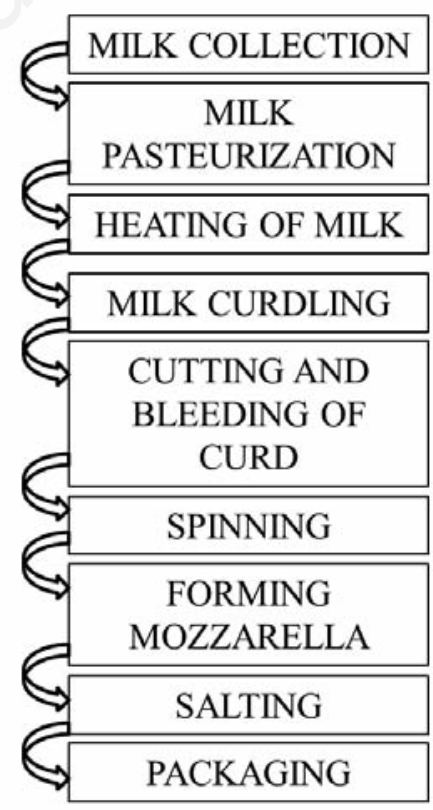

Figure 1. Buffalo's mozzarella production process.

Table 2. Mean values of indoor and outdoor air temperature and relative humidity, clothing insulation and metabolic rate.

\begin{tabular}{|c|c|c|c|c|c|c|}
\hline $\begin{array}{l}\text { Date } \\
\text { of measurement }\end{array}$ & $\begin{array}{c}\text { Indoor air } \\
\text { temperature } \\
{\left[{ }^{\circ} \mathrm{C}\right]}\end{array}$ & $\begin{array}{c}\text { Indoor relative } \\
\text { humidity } \\
{[\%]}\end{array}$ & $\begin{array}{c}\text { Outdoor air } \\
\text { temperature } \\
{\left[{ }^{\circ} \mathrm{C}\right]}\end{array}$ & $\begin{array}{c}\text { Outdoor relative } \\
\text { humidity } \\
{[\%]}\end{array}$ & $\begin{array}{c}\mathrm{I}_{\mathrm{cl}} \\
{[\mathrm{clo}]}\end{array}$ & $\begin{array}{c}M \\
{\left[\mathrm{~W} \mathrm{~m}^{-2}\right]}\end{array}$ \\
\hline April, $10^{\text {th }}$ & 20.9 & 65.3 & 16.6 & 51.4 & 0.7 & 116 \\
\hline May, $03^{\text {rd }}$ & 22.9 & 64.8 & 21.1 & 59.2 & 0.7 & 116 \\
\hline May, $30^{\text {th }}$ & 22.7 & 78.4 & 17.1 & 56.6 & 0.7 & 116 \\
\hline June, $11^{\text {th }}$ & 263 & 61.5 & 23.1 & 54.3 & 0.7 & 116 \\
\hline June, $17^{\text {th }}$ & 32.7 & 53.5 & 31.4 & 29.7 & - & - \\
\hline
\end{tabular}


15.31

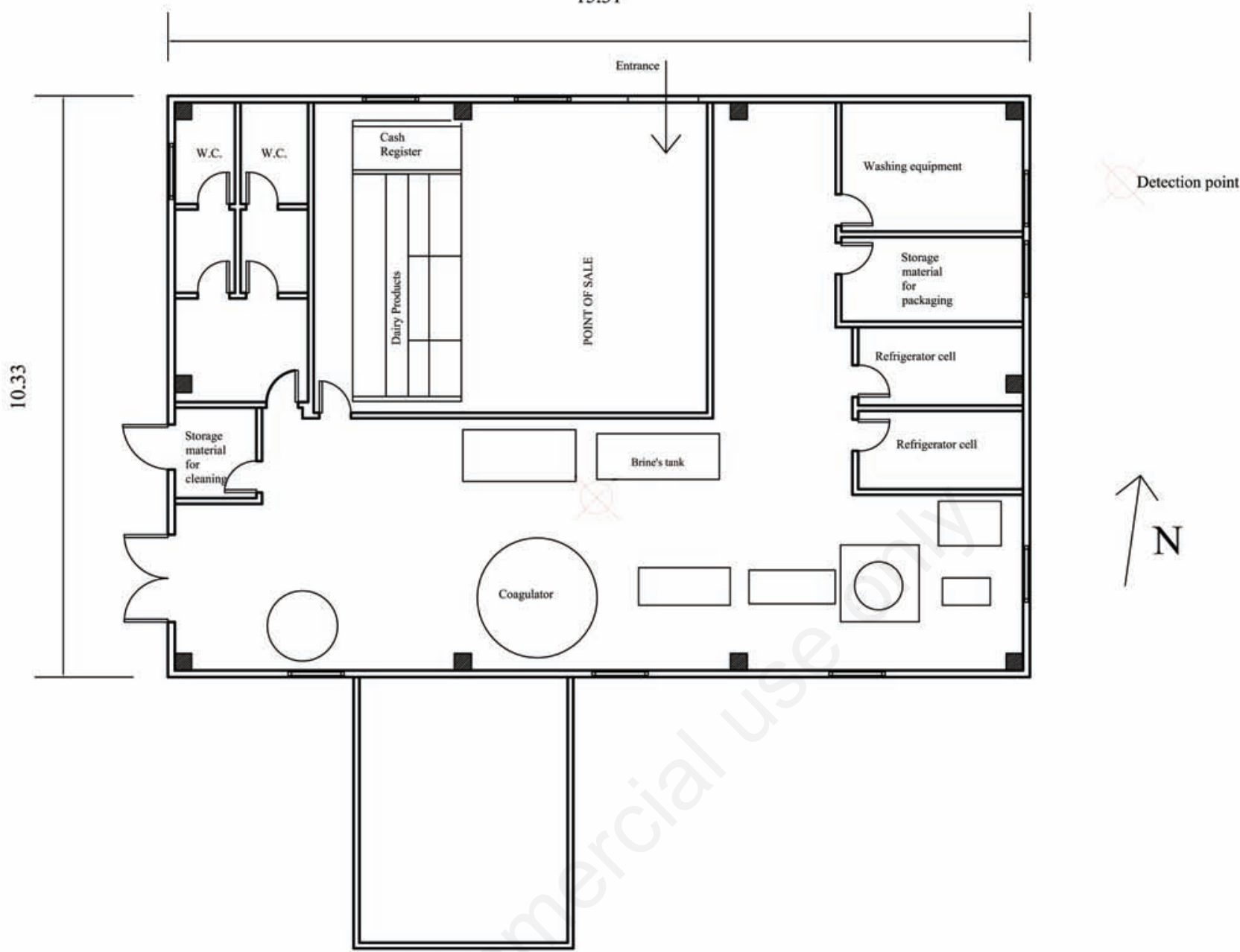

Figure 2. Plan of the dairy farm studied.

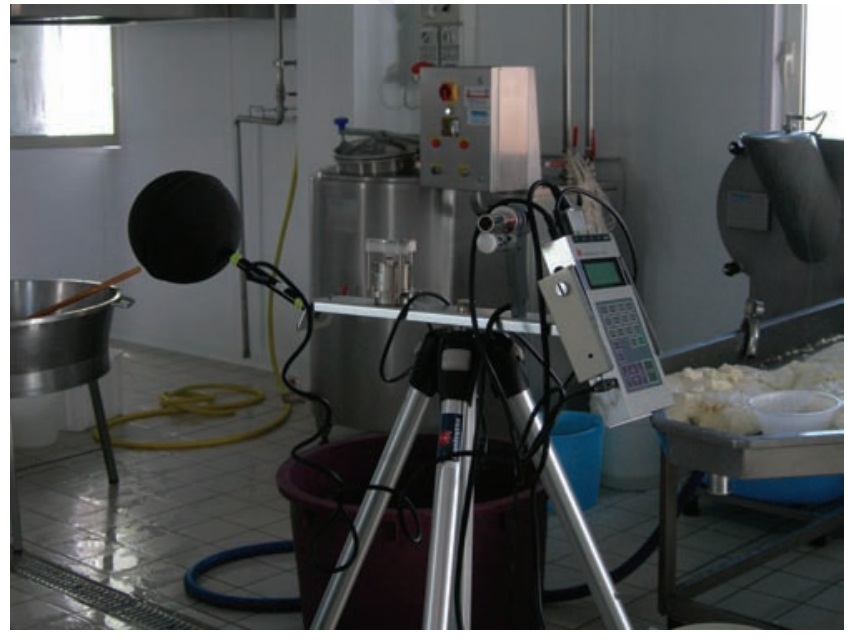

Figure 3. Measurement system used for the research.

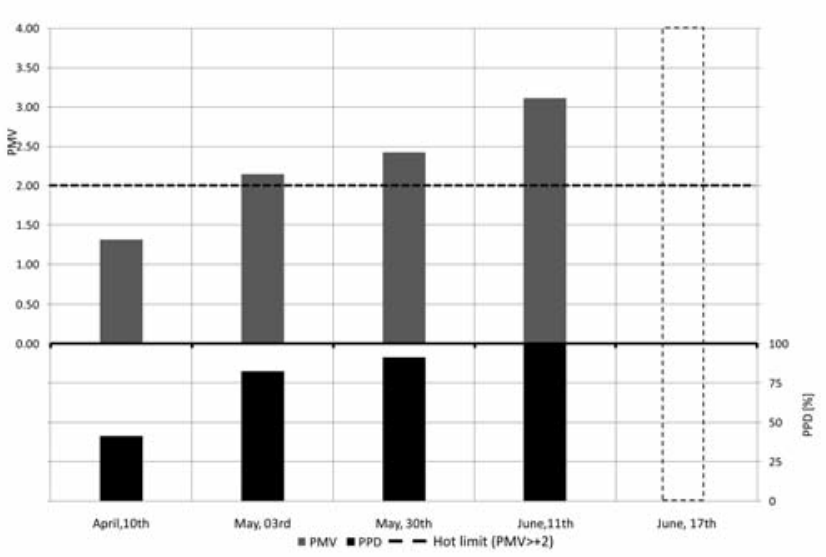

Figure 4. Predicted mean vote (PMV), predicted percentage of dissatisfied (PPD) and PMV limit established by the respective reference standards. 


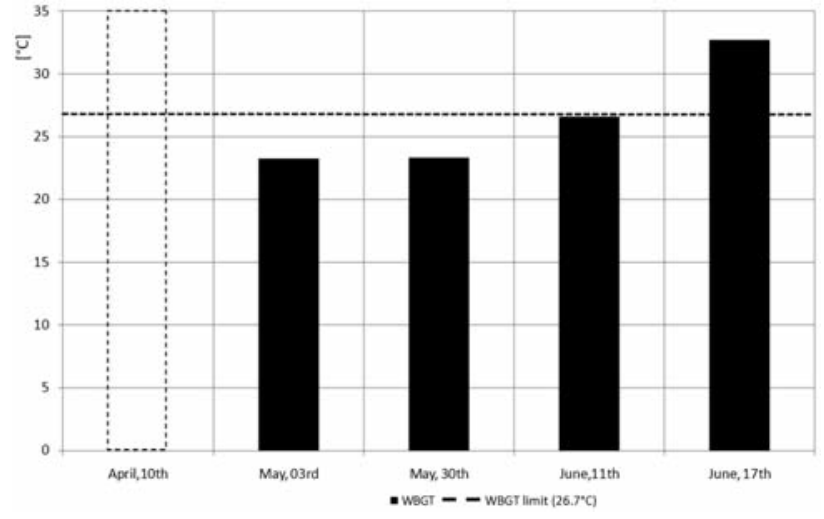

Figure 5. Mean values of wet-bulb globe temperature (WBGT) index for the periods of experimentation.

with $\mathrm{I}_{\mathrm{cl}}=0.70$ clo to another with $\mathrm{I}_{\mathrm{cl}}=0.50$ clo. This would allow reducing the operator's acclimatization and would reduce the PMV index of $33 \%$.

In the first half of June, the WBGT exceeds the limit set for acclimated workers and the employees find themselves operating under thermal stress conditions. Since the WBGT index, unlike the PMV, is closely related to the air temperature you could intervene further reducing the value, whose control is generally entrusted only to the forced ventilation through fume hood. It is possible to reduce the indoor air temperature through a cooling system or, in the design phase of the building, to foresee the use of materials or construction techniques that improve the thermal insulation. Additional actions may be even the clothing of the operators described above and the programming of one or more breaks during the working shift to spend in areas of acclimatization.

\section{Conclusions}

The calculation of the indices, brought in accordance with the safety standards, has allowed us to assess the degree of risk of heat stress they are subjected to the operators involved in the preparation of buffalo's mozzarella in a dairy farm. The survey data showed the presence of different situations of heat stress risk.

During the second part of the spring season (late April to mid June) the Steelworkers of buffalo's mozzarella, under the climatic conditions in which it is located the dairy farm, are in the presence of a situation of thermal discomfort because the calculated WBGT index not exceeds the threshold established by the legislation but at the same time the relative values of PMV calculated classify the workplace as a moderate warm environment. In the last study period (mid-June) in the vicinity of the summer and in presence of significantly higher air temperatures, it is possible to affirm that operators are in presence of heat stress conditions. In order to reduce this risk situation, the employer is required to: i) provide appropriate clothing in order to reduce the $\mathrm{I}_{\mathrm{cl}}$ index; ii) check the exposure times with programming breaks to spend in areas of acclimatization; iii) reduce the internal air temperature of the workplace through an adequate air conditioning system.

\section{References}

Alfano G., D’ambrosio R.F., Riccio G. 1998. Disagio e stress termico: effetti, normative, valutazione e controllo. pp 531-566 in Proc. dBA 1998: Dal rumore ai rischi fisici; valutazione, prevenzione bonifica degli ambienti di lavoro, Modena, Italy.

Budd G.M. 2008. Wet-bulb globe temperature (WBGT): its history and its limitation. J. Sci. Med. Sport 11:20-32.

Callejon-Ferre A.J., Manzano-Agugliaro F., Diaz-Perez M., CarrenoSanchez J. 2011. Improving the climate safety of workers in Almeria-type greenhouse in Spain by predicting the periods when they are most likely to suffer thermal stress. Appl. Ergon. 42:391-6.

Di Giacinto S., Colantoni A., Cecchini M., Monarca D., Moscetti R., Massantini R. 2012. Dairy production in restricted environment and safety for the workers. Industrie Alimentari 530:5-12.

ISO, 1996. Hot environments. Estimation of the heat stress on working man, based on the WBGT index (wet bulb globe temperature). UNI EN ISO 27243:1996. International Organization for Standardization Publ., Geneva, Switzerland.

ISO, 2002. Ergonomics of the thermal environment - Instruments for measuring physical quantities. UNI EN ISO 7726:2002. International Organization for Standardization Publ., Geneva, Switzerland.

ISO, 2005. Ergonomics of the thermal environment Determination of metabolic rate. UNI EN ISO 8996:2005. International Organization for Standardization Publ., Geneva, Switzerland.

ISO, 2006. Ergonomics of the thermal environment - Analytical determination and interpretation of thermal comfort using calculation of the PMV and PPD indices and local thermal comfort criteria. UNI EN ISO 7730:2006. International Organization for Standardization Publ., Geneva, Switzerland.

ISO, 2009. Ergonomics of the thermal environment. Estimation of thermal insulation and water vapour resistance of a clothing ensemble. UNI EN ISO 9920:2009. International Organization for Standardization Publ., Geneva, Switzerland.

Marras T., Murgia L., Pazzona A, 2005. Valutazione del rischio biomeccanico in due caseifici industriali con differente grado di meccanizzazione. G. Ital. Med. Erg. 27:112-18.

Marucci A., Monarca D., Cecchini M., Colantoni A., Biondi P., Cappuccini A. 2013. The heat stress for workers employed in laying hens houses. J. Food Agric. Environ. 11:20-4.

Marucci A., Pagniello B., Monarca D., Cecchini M., Colantoni A., Biondi P. 2012. Heat stress suffered by workers employed in vegetable grafting in greenhouses. J. Food, Agric. Environ. 10:1117-21.

Monarca D., Bedini R., Cecchini M., Colantoni A., Di Giacinto S., Marucci A., Menghini G., Porceddu P.R. 2012. Il rischio da microclima nei caseifici e nelle sale di mungitura. In: Giornata di studio "Salute e sicurezza sul lavoro nel comparto zootecnico e caseario", Sassari, 26 ottobre 2011. Available from: http://www.progettoprevenzione.net/index.php/8-sicurezza-lavoro/210-microclima-caseifici

Moran D.S., Pandolf K.B., Shapiro Y., Heled Y., Shani Y., Mathew W. T., Gonzalez R.R. 2001. An environmental stress index (ESI) as a substitute for the wet bulbe temperature (WBGT). J. Thermal Biol. 26:427-31.

Pérez-Alonso J., Callejón-Ferre Á.J., Carreño-Ortega Á., SánchezHermosilla J. 2011. Approach to the evaluation of the thermal work environment in the greenhouse-construction industry of SE Spain. Build. Environ. 46:1725-34. 